\title{
Sanitary Condition Of Some Hand Dug Wells In Zaria City, Northern Nigeria.
}

\author{
Abduljalal Abdulsalam ${ }^{1,}$ Sule Muhammad Zubairu ${ }^{2}$ \\ ${ }^{1}$ Department of General Studies, Nuhu Bamalli Polytechnic, Zaria. \\ ${ }^{2}$ Department of Geography, Ahmadu Bello University, Zaria.
}

\begin{abstract}
This paper examines the sanitary-risk factors in relation to some hand-dug wells in Zaria city of Kaduna State. Ten (10) wells were randomly selected from city-wards and field inspections of the wells were conducted in each selected ward. The simple percentage was carried out for analysis of data. The results indicated that 80 percent of the wells were within $10 \mathrm{~m}$ of latrines, while 70 percent of the wells were very close to a source of pollution at about $10 \mathrm{~m}$ radius. The study recommended that vigorous environmental education programmes should be embarked upon to public on a proper ethics of citing wells. There should be sanitary inspection of the source of water as a routine activity.
\end{abstract}

Keywords: Assessment, Hand-dug wells, Sanitary-risk factors

\section{Introduction}

Many tens of millions of families worldwide particularly in developing countries still depend on private and public dug wells as their major source of water. Open or poorly covered well heads pose the commonest risk to well-water quality, since the water may be contaminated by the use of inappropriate waterlifting devices by consumers. The most serious source of pollution is contamination by human and animal waste from latrines, septic tanks, refuse dump, dust particles and manure resulting in increased levels of microorganisms including pathogens.

Most of drinking water which is being utilized in Zaria City is essentially derived from hand dug wells. Many wells have been exposed to sanitary-risk factors which may threaten the quality of the water. It is in this regard that technical assessments such as sanitary survey to demonstrate the level of the risk to the consumers of these wells are therefore very important.

It is often useful to be determining the importance of different risk factors in order to direct investment and action on those improvements in the source that will yield the greatest improvements in water quality. In this regard, sanitary inspection provides an easy, but effective means of monitoring hand-dug well protection/sanitary completion, particularly when employs a standardized and quantifiable approach (Lloyd and Bartram, 1991; Lloyd and Helmer, 1991). Such an approach is often particularly useful in order to assess whether microbiological contamination of groundwater derives from poorly sited and constructed sanitation facilities or from poor maintenance of sanitary completion measures. Leaching from on-site sanitation has been identified in some cases to be the major cause (Massone et al., 1998; Melian et al., 1999; Rahman, 1996; Booynakarnkul and Lloyd, 1994). In developing countries, the use of poorly protected groundwater sources has been linked to acute diarrhoeal disease (Trivedi et al., 1971; Nasinyama et al., 2000).

It is in the light of the afore-mentioned fact that, the research work seeks to answer the following research questions.

I. Is there a latrine within $10 \mathrm{~m}$ of the well?

II. Is the nearest latrine on the higher ground than the well?

III. Is there any other source of pollution (e.g animal excreta, rubbish) within $10 \mathrm{~m}$ of the well?

IV. Are the rope and bucket exposed to contamination?

$\mathrm{V}$. Is the height of the headwall (parapet) around the wall adequate?

VI. Is the concrete apron around the well less than $1 \mathrm{~m}$ wide?

VII. Are the walls of the well (well-lining) inadequately sealed?

\subsection{Study Area}

\section{II. materials and methods}

Zaria is located in north central Nigeria on longitude $11^{\circ} 04^{\prime} \mathrm{N}$ and latitude $7^{0} 42^{\prime} \mathrm{E}$. It is situated about $83 \mathrm{~km}$ North of Kaduna along Kaduna-Kano high way, $128 \mathrm{~km}$ South-East of Kaduna as observed by mortimore, (1979). Indeed, Hore (1970), maintained that the study area is located on a plateau at a height of about $0.67 \mathrm{~km}$ above the mean sea level and more than $643.71 \mathrm{~km}$ away from the sea and possesses a tropical Savanna climate with distinct wet and dry seasons. The area belongs to the Precambrian basement complex of northern Nigeria. 
It is composed of three rock types which include the basement gneiss, porphyritic granite and medium grained granite.

The methodology includes the following steps:

\subsection{Survey of sanitary conditions}

A total of Ten (10) wells were randomly selected from the study area. Visual inspection of the handdug wells in relation to sanitary-risk factors were conducted in each selected ward. The preliminary field inspection was carried-out to find out the proximity of the wells to latrines and other sources of pollution (e.g animal excreta, rubbish), nature of surrounding, well-lining, rope and bucket used in the redraw of water from the well, nature of headwall (parapet) and concrete floor around the well, drainage condition among others.

\subsection{Analysis of Data} in table.

The simple percentage was carried out for the analysis of data. Meanwhile, the findings were presented

\section{Results And Discussion \\ 3.1 Assessment of hand-dug wells in relation to sanitary-risk factors}

The results of the field inspection for the sanitary condition of hand-dug wells in Zaria are presented in Table 1. It was discovered that, 80 percent of the wells were within $10 \mathrm{~m}$ of the latrines, while 70 percent of the wells were very close to the source of pollution (e.g dumpsites, animal excreta) within 10m radius. This signifies that, most of the inhabitants were ignorant of indiscriminate positioning of wells in relation to sanitaryrisk factors.

Table 1. Sanitary assessment of hand-dug wells

\begin{tabular}{|lcc|}
\hline Sanitary-risk factors & Number of Wells & Percentage \\
Latrine within 10 $\mathrm{m}$ of the well & 8 & $80 \%$ \\
Source of pollution within 10m of the well & 7 & $70 \%$ \\
Poor drainage within $2 \mathrm{~m}$ of the well & 6 & $60 \%$ \\
Faulty drainage channel & 6 & $60 \%$ \\
Lack of headwall & 4 & $40 \%$ \\
Concrete of less than $1 \mathrm{~m}$ around the well & 8 & $80 \%$ \\
Lack of well-lining & 7 & $70 \%$ \\
Cracks in concrete floor around the well & 7 & $70 \%$ \\
Rope and bucket exposed to contamination & 9 & $90 \%$ \\
Wells exposed to animal excreta & 8 & $80 \%$ \\
\hline
\end{tabular}

Source: Field Survey, 2010

It is evident that, there is poor drainage, causing stagnant water within $2 \mathrm{~m}$ in 60 percent of the wells. Similarly, the study revealed that, a faulty drainage channel existed for 60 percent of the wells. Meanwhile, 40 percent of the headwall (parapet) around the wells were inadequate, allowing surface water to enter the wells. About 70 percent of the wells (well-lining) were not adequately sealed with the exception of 30 percent of the wells. The rope and bucket being used to draw water from the wells for almost 90 percent of the selected handdug wells are exposed to contamination (e.g by being left on the stagnant water around the wells, rubbish). In the same vein, there is no provision of concrete floor apron around 80 percent of the wells of $1 \mathrm{~m}$ wide, but 20 percent of the wells are notable exception. Survey has shown that, 80 percent of the wells were not adequately fenced to keep animals away.

Based on the study carried-out from the study almost 90 percent of the inhabitants consume water from their respective wells without any form of purification. They also use same for other domestic uses such as cooking, laundry, bathing, environmental hygiene, religious activities among others.

\section{Conclusion}

Conclusively, the paper has critically assessed the sanitary conditions of some wells from the study area. The finding reveals that, the hand dug well were exposed to high sanitary risk-factors, arising from close proximity to pit latrine, source of pollution especially dumpsites, animal excreta, gutters (waste water channels) and exposure to contamination by the rope and bucket being used to draw water from the wells among others. It is recommended that, wells should be located on a minimum safe distance (MSD) of a least 10m away from the latrines. Meanwhile, the nearest latrine should on the higher ground than the well. More importantly, sanitary inspection on the source of water should be embarked as routine activity by a public water supply agency. 


\section{References}

[1] B. Lloyd and J. Bartram, Surveillance solution to microbiological problems of water quality control in developing countries. 24(2), 1991, 61-75

[2] B. Lloyd and R. Helmer, Surveillance of drinking-water quality in rural areas ( London: Longman, 1991)

[3] T. Boonyakarnkul and B.J Lloyd, The impact of rehabilitation on tube well water quality using combined sanitary inspection and bacteriological analysis. Paper presented at the $2^{\text {nd }}$ Asian Regional Workshop on Groundwater Contamination, Adelaide, South Australia. 1994.

[4] G.W. et al, Nasinyama, Risk factors for acute diarrhea among inhabitants of Kampala District, Uganda South Africa Medical Journal. 90(9), 2000, 891-898.

[5] M.B Thorp, Landscape evolution. In Mortimore, MJ. (ed.) Zaria and its region. Occasional Paper No. 9, Ahmadu Bello University: Zaria, Nigeria. 1970

[6] P.N Hore, Weather and Climate in Zaria and Its Region. In: Mortimore. M.J. (Ed.). Zaria and Its Region. Occasional Paper No. 4. Department of Geography, Ahmadu Bello University: Zaria, Nigeria. 1970, 41 - 54.

[7] S. Michael and S. Rod, Sanitary Surveying, WEDC Technical-brief No. 50, Loughborough University Leicestershire LE11 3TU United Kingdom. 1999, 69-72.

\subsection{Check-list}

\section{Appendix}

\section{A. General Information}

\section{Sanitary Assessment Form Of Hand-Dug Well}

Ward

Water Sample Code no

Date of Visit

\section{B. Identification of Sanitary-risk factors}

1. Is there a latrine within $10 \mathrm{~m}$ of the well?

2. Is the nearest latrine on the higher ground than the well?

3. Is there any other source of pollution (e.g animal excreta, rubbish) within $10 \mathrm{~m}$ of the well?

4. Is there poor drainage, causing stagnant water within $2 \mathrm{~m}$ of the well?

5. Is there a faulty drainage channel? Is it broken, allowing ponding?

6. Is the headwall (parapet) around the well inadequate, allowing surface water to enter the well?

7. Is the concrete floor less than $1 \mathrm{~m}$ wide around the well?

8. Are there walls of the well (well-lining) inadequately sealed?

9. Are there any cracks in the concrete floor around the well which could permit water to enter the well?

10. Are the rope bucket exposed to contamination?

Sanitary risk score:

$$
\text { 9, } 10 \text {-Very high }
$$
6, 7, 8 - High
3, 4, 5 - Moderate
$0,1,2-$ Low

Signature of Sanitarian 